\title{
Cloning expression and immunogenicity analysis of inhibin gene in Ye Mule Aries Sheep
}

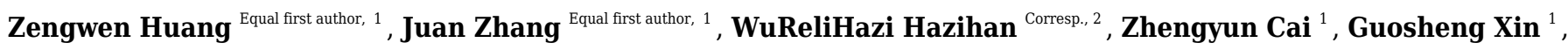 \\ Xiaofang Feng ${ }^{1}$, Yaling Gu ${ }^{\text {Corresp. } 1}$ \\ ${ }^{1}$ Agriculture College, Ningxia University, Yinchuan, China \\ 2 College of Animal Science and Technology, Shihezi University, Shihezi, China \\ Corresponding Authors: WuReliHazi Hazihan, Yaling Gu \\ Email address: 1508217366@qq.com, guyaling@sina.com
}

Background: Ye Mule Aries is one of the most important sheep breeds in Xinjiang, China. This breed is well adapted to harsh environmental conditions and displays strong disease resistance, fast growth, and high cold tolerance. To analyze the clonal expression and immunogenicity of the Ye Mule Aries sheep inhibin gene, total RNA was extracted from sheep ovarian tissue and used as a template to generate a eukaryotic expression vector and study inhibin immunogenicity.

Methods: Primers were designed to amplify the inhibin A gene via polymerase chain reaction and the amplified product was cloned between the Scall and EcoRI restriction sites of the expression vector pEGFP-N1 to construct a recombinant plasmid, pEGFP-INH $\alpha$. Following the validation of successful cloning, the pEGFP-INH $\alpha$ plasmid was transfected into BHK cells to verify expression in eukaryotes and subsequently utilized as an antigen in rabbits. Rabbits were tested for anti-inhibin antibodies and serum follicle-stimulating hormone (FSH) concentrations.

Results: The analysis of the INH $\alpha$ gene sequence revealed that INH $\alpha$ is $1109 \mathrm{bp}$ long and is translated to an approximately $40 \mathrm{KDa}$ protein. Bioinformatics approach indicated that the INH $\alpha$ gene is highly conserved between organisms. Immunization with the eukaryotic expression vector, pEGFP-INH $\alpha$, which expresses the INH $\alpha$ gene elicited immune response and generation of anti-INH $\alpha$ antibody. The antibody had a significant regulatory effect on the serum concentration of FSH in rabbits and led to higher levels of $\mathrm{FSH}$, indicating increased ovary function.

Conclusions: The present work resulted in a successful construction of eukaryotic expression plasmid pEGFP-INH $\alpha$ and verified the immunogenicity of this highly conserved protein. Further, the expression of pEGFP-INH $\alpha$ was shown to have a significant impact on the secretion of FSH, indicating a potential regulatory role in ovarian function. In conclusion, our current findings can serve as a working model for studying the effect of INH $\alpha$ on the breeding performance of Ye Mule Aries sheep, providing a novel strategy to improve their reproduction rates. 
1 Cloning expressionand immunogenicity analysis of inhibin gene in

\section{Ye Mule Aries Sheep}

\section{Abstract}

4 Background: Ye Mule Aries is one of the most important sheep breeds in Xinjiang, China. This breed is

5 well adapted to harsh environmental conditions and displays strong disease resistance, fast growth, and

6 high cold tolerance. To analyze the clonal expression and immunogenicity of the Ye Mule Aries sheep

7 inhibin gene, total RNA was extracted from ovarian tissue and used as a template to generate a eukaryotic expression vector and study inhibin immunogenicity.

9 Methods: Primers were designed to amplify the inhibin A gene via a polymerase chain reaction. The amplified product was cloned between the ScalI and EcoRI restriction sites of the expression vector pEGFP-

N1 to construct a recombinant plasmid, pEGFP-INH $\alpha$. Following the validation of successful cloning, the pEGFP-INH $\alpha$ plasmid was transfected into BHK cells to verify expression in eukaryotes and subsequently utilized as an antigen in rabbits. Rabbits were tested for anti-inhibin antibodies and serum folliclestimulating hormone (FSH) concentrations.

Results: The analysis of the INH $\alpha$ gene sequence revealed that INH $\alpha$ is $1109 \mathrm{bp}$ long and is translated to an approximately $40 \mathrm{KDa}$ protein. Bioinformatics approach indicated that the INH $\alpha$ gene is highly conserved between organisms. Immunization with the eukaryotic expression vector, pEGFP-INH $\alpha$, which expresses the INH $\alpha$ gene, elicited immune response and generation of anti-INH $\alpha$ antibody. The antibody had a significant regulatory effect on the serum concentration of FSH in rabbits and led to higher levels of 
FSH, indicating an increased ovary function.

21 Conclusions: The present work resulted in a successful construction of eukaryotic expression plasmid

22 pEGFP-INH $\alpha$ and verified the immunogenicity of this highly conserved protein. Moreovoer, the expression

23 of pEGFP-INH $\alpha$ had a significant impact on the secretion of FSH, indicating a potential regulatory role of

24 INH $\alpha$ in ovarian function. In conclusion, our current findings can serve as a working model for studying

25 the effect of INH $\alpha$ on the breeding performance of Ye Mule Aries sheep, providing a novel strategy to

26 improve their reproduction rates.

\section{Background}

In 1932, McCullough established that a factor contained in the aqueous extract of bovine testes exerted negative feedback on follicle-stimulating hormone (FSH) secretion; the factor was named "inhibin" (INH or IB) ${ }^{[1]}$. INH is a glycoprotein hormone secreted by testicular supporting cells and ovarian granulosa cells.

The functional form of INH is a dimer containing two disulfide bonds between $\alpha$ - and $\beta$ - subunits, as well as glycosylation sites on the base ${ }^{[2]}$. In mammals, the $\beta$-subunit has two isoforms, A and B. Therefore, INH is expressed in two forms: INHA $(\mathrm{a} A)$ and INHB $(\mathrm{a} \beta \mathrm{B})^{[3]}$. It has been demonstrated that INH is the main negative feedback regulator of FSH secretion in mammals, suppressing the secretion of FSH in the pituitary gland ${ }^{[4-8]}$. Moreover, the levels of INH can reflect the amount of follicle growth at the beginning of the menstrual cycle, serving as a key regulator of ovulation in animals ${ }^{[9]}$. Additionally, INH acts locally,

37 directly inhibiting follicular function and development of gonads ${ }^{[10-12]}$. Several studies demonstrated that

38 female animals immunized against INH enter the puberty earlier, show an increase in ovulation rate, and 
40 and lambing in sheep ${ }^{[15-17]}$ and have a similar effect on ovulation and litter size in pigs and cattle ${ }^{[18-19]}$.

41 Immunization of rats with either an INH and GFP fusion gene or an inhibin gene vaccine and

42 immunoadjuvant leads to the production of anti-inhibin antibody ${ }^{[20-21]}$.Moreover, the INH gene-based

43 vaccine immunization can effectively induce an immune response in postpartum dairy cows ${ }^{[22]}$. It was also

44 shown that immunization of cows with INH enhances ovulation levels, resulting in an increased number

45 and quality of embryos ${ }^{[23-24]}$. Active INH immunization can also produce similar effects in goats ${ }^{[25,26]}$.

46 Recent developments in molecular biology elucidated the significance of INH in regulating the reproductive

47 function of animals. Therefore, based on studies in mice, poultry, pigs, cattle, sheep and other animals, INH

48 immunization has the potential to improve animal fecundity, which is of great significance in both scientific

49 research and agricultural production.

50 Ye Mule Aries (formerly known as Kalamu Mule) is a flock of sheep located in the western margin of

51 the Junggar Basin in Emin County, Tacheng District, Xinjiang, China ${ }^{[27]}$. The Ye Mule Aries sheep,

52 characterized by a small fat hip and fat body, were created in the $19^{\text {th }}$ century through the long-term breeding

53 of Kazakh sheep in a unique geographical location with a specific climate ${ }^{[28]}$. Due to its desirable

54 characteristics, the Ye Mule Aries sheep was heavily utilized in the development of the meat industry, in

particular for lamb production in Xinjiang, leading to a sharp decline in the number of purebred sheep in

56 Xinjiang. The decrease in population size has made the selection and breeding process challenging and

57 placed the animals in danger of extinction. To overcome this problem and design the strategy to protect Ye

58 Mule Aries sheep population and improve their productivity, the Ye Mule Aries inhibin subunit $\alpha$ (INH $\alpha$ ) 
60

61

62

63

that eukaryotic expression of the pEGFP-INH $\alpha$ vector can increase ovulation rate in adult rabbits. The accumulated results demonstrated that the expression of the INH $\alpha$ vector significantly improved the ovulation rate in rabbits, providing a rationale for future studies involving gene vaccination.

\section{Materials and Methods}

Ethics statement: All animal care and experimental procedures were approved by the Animal Protection and Use Committee of Ningxia University and Shihezi University. All research was carried out in strict accordance with Ningxia University and Shihezi University experimental animal welfare and ethical guidelines.

Experimental animals: Ye Mule Aries were provided by Sheep Farm, Ermin County, Xinjiang, and Japanese big white rabbits were provided by Animal Experimental Center of Shihezi University. Animals were utilized during the estrus period.

Materials: The cloning vector pMD18-T, DH5 $\alpha$ bacteria, BHK cells, and eukaryotic expression plasmid pFGFP-N1 were all provided by the Oasis Ecological Laboratory of Xinjiang Production and Construction Corps of China. Lipofectamine 2000 was obtained from Invitrogen, T4 DNA ligase, 10xT4 DNA ligase buffer, and other molecular biology reagents were provided by TIANGEN, Takala, Kangwei Companies.

\section{Collection of Ye Mule Aries sheep ovarian tissue}

The ovaries of purebred Ye Mule Aries sheep (healthy ewes that normally produce 3 fetuses) were collected from animals from the pastoral area of Halamumul Township, Emin County, Xinjiang. The ovaries were collected in $1.5 \mathrm{~mL}$ centrifuge tubes and placed in a gauze bag. Subsequently, the ovaries were 
snap-frozen in liquid nitrogen and stored at $-80^{\circ} \mathrm{C}$ until use.

\section{Extraction of total RNA and the design of synthetic primers}

After thoroughly grinding the collected ovarian tissue in liquid nitrogen, total RNA was extracted according to the specification of TRNzol total RNA extraction kit (TIANGEN) and stored at $-80{ }^{\circ} \mathrm{C}$. Because eukaryotic genes contain introns, the total RNA of Ye Mule Aries ovary tissue was amplified by RT-PCR to obtain the cDNA fragment of INH $\alpha$ subunit. Primers were designed on the basis on the fulllength sequence of INH $\alpha$ (GenBank, XM 004.004955.1). The expected amplified product fragment size was 1100 bp. The upstream primer, 5'-ATG TGG CTT CAG CTG CTC CTC TTC-3', and downstream primer, 5-' $G A T$ GCA AGC ACA GTG CTG GGT G-3', were synthesized by Shanghai Shenggong Bioengineering Co., Ltd.

\section{Reverse transcription, PCR amplification, and ligation of the INH $\alpha$ gene and vector}

Reverse transcription was carried out using a reagent kit (Takala) according to the manufacturer's instructions. The reaction mixture, $20 \mu \mathrm{L}$, consisted of 5x Mix (4 $\mu \mathrm{L})$, RNA ( $2 \mu \mathrm{g})$, and RNase-free water $(16 \mu \mathrm{L})$. The reaction was performed at $37^{\circ} \mathrm{C}$ for $15 \mathrm{~min}$ followed by $85^{\circ} \mathrm{C}$ for $5 \mathrm{sec}$; the product was stored at $-4{ }^{\circ} \mathrm{C}$.

PCR of the cDNA was performed according to the TaKaRa kit instructions using primers synthesized by Shanghai Biotech Co., Ltd., to obtain the target gene INH $\alpha$. The reaction mixture, $25 \mu \mathrm{L}$, consisted of $2 \mathrm{x}$ Mix $(12.5 \mu \mathrm{L})$, upstream and downstream primers $(100 \mu \mathrm{mol} / \mathrm{L}, 0.4 \mu \mathrm{L}$ each), double-distilled water $(9.7$ $\mu \mathrm{L})$, and cDNA $(2 \mu \mathrm{L}, 1.9 \mathrm{ng} / \mu \mathrm{L})$. After pre-denaturation at $94{ }^{\circ} \mathrm{C}$ for $5 \mathrm{~min}, 35$ cycles of $94{ }^{\circ} \mathrm{C}$ for $40 \mathrm{~s}, 68$ 
${ }^{\circ} \mathrm{C}$ for $40 \mathrm{~s}$, and $72{ }^{\circ} \mathrm{C}$ for $1 \mathrm{~min} 30 \mathrm{~s}$ were performed, followed by a final extension at $72^{\circ} \mathrm{C}$ for $7 \mathrm{~min}$. The amplified product was subjected to electrophoresis on $1.0 \%$ agarose gel.
After the electrophoresis, DNA was recovered and purified according to the instructions of the QuickGel

Extraction Kit (Kangwei Co.). Subsequently, the amplified sequence was ligated into the pMD18-T vector at $16^{\circ} \mathrm{C}$ overnight. DH5a competent cells were transformed with the ligation product and cultured overnight on LB-coated plates containing $50 \mu \mathrm{g} / \mathrm{mL}$ ampicillin. Five positive clones were selected, and the identity of the recombinant plasmid was initially confirmed by PCR and double enzyme digestion.

\section{Sequencing of the INH $\alpha$ gene and pMD18-T vector}

The clones were sequenced by Shanghai Shenggong Bioengineering Co., Ltd. Obtained cDNA sequences were analyzed using DNA-MAN, DNAStar, and Chromas software, as well as by the comparison of the sequence alignment with the Ara cDNA in the GenBank database (accession number XM-004004955).

\section{Construction and characterization of pEGFP-INH $\alpha$ plasmid}

The pMD18-INH $\alpha$ plasmid and the eukaryotic expression vector $\mathrm{pECrFP-N1}$ were cut at restriction sites by ScalI and EcoRI enzymes for $4 \mathrm{~h}$ at $37^{\circ} \mathrm{C}$. The digested products were subjected to electrophoresis on $1.0 \%$ agarose gel, and recovered and purified using a gel recovery kit. The reaction mixture for the construction of recombinant plasmid pEGFP-INH $\alpha$ consisted of the fragment of the pMD18 plasmid containing INH $\alpha(6 \mu \mathrm{L}, 1.9 \mathrm{ng} / \mu \mathrm{L})$, eukaryotic expression vector pECrFP-N1 (1 $\mu \mathrm{L}, 1.9 \mathrm{ng} / \mu \mathrm{L})$, T4 DNA Ligase $(1 \mu \mathrm{L}), 10 \mathrm{x}$ T4 DNA ligase buffer $(2 \mu \mathrm{L})$, and double-distilled water $(10 \mu \mathrm{L})$, for a total volume of $20 \mu \mathrm{L}$. The ligation reaction was carried out overnight at $16^{\circ} \mathrm{C}$. The ligation product was transformed into E. coli DH5a competent cells, plated on plates containing LB medium with $50 \mu \mathrm{g} / \mathrm{mL}$ kanamycin, and 
118

119

120

121

122

123

cultured overnight at $37^{\circ} \mathrm{C}$. Five positive clones were randomly selected and the recombinant $p E G F P-I N H \alpha$ plasmid was identified by PCR and double enzyme digestion.

\section{Sequencing of the pEGFP-INHa plasmid}

The five pEGFP-INH $\alpha$-positive clones were sequenced by Shanghai Shenggong Bioengineering Technology Service Co., Ltd. Obtained cDNA sequences were analyzed with DNA-MAN, DNAStar, and Mega 5.0 software, and aligned to the INH $\alpha$ subunit gene sequence in the GenBank database.

\section{Transfection of BHK cells and identification of pEGFP-INH $\alpha$ positive cells}

The recombinant pEGFP-INH $\alpha$ plasmid was purified and recovered. The plasmid was mixed with Lipofectamine 2000 at a ratio of $4: 1$ and incubated with BHK cells at $37^{\circ} \mathrm{C}$ in the presence of $5 \% \mathrm{CO}_{2}$. After $48 \mathrm{~h}$, over $50 \%$ of the cells were positive for green fluorescent protein (GFP), as determined under an inverted epifluorescence microscope. Cells were harvested and divided into two groups, which were subjected to RT-PCR and Western blot analysis, respectively.

\section{Preparation of immunogens and immunization of rabbits}

The eukaryotic expression plasmid pEGFP-INH $\alpha$ (optical density ratio OD260/OD280 of 1.8) was mixed with Lipofectamine 2000 to yield the final concentration of $1 \mathrm{mg} / \mathrm{mL}$. The rabbits to be immunized were injected with $0.2 \mathrm{~mL}$ of $0.5 \%$ procaine hydrochloride into the muscles on both sides of the leg at 24 and 2 $\mathrm{h}$ before the immunization. Each rabbit received an injection of $0.2 \mathrm{~mL}$ of the plasmid $(1 \mathrm{mg} / \mathrm{mL})$ at the same site. After 10 days, the rabbits were immunized again by injection at the same site, but the immunization dose was halved. Control rabbits received an equal amount of physiological saline.

\section{Determination of antibody levels}


138

139

140

141

142

143

144

145

146

147

148

149

150

151

152

153

154

155

156

Antibody levels in the serum of experimental and control rabbits were determined by enzyme-linked immunosorbent assay (ELISA). For this purpose, $100 \mu \mathrm{L}$ of a coating solution containing $15 \mu \mathrm{g}$ of the antigen was added to the wells of a plate and incubated overnight at $4{ }^{\circ} \mathrm{C}$. Blood samples were diluted 1:12800 with $5 \%$ skim milk, and $100 \mu \mathrm{L}$ aliquot was added to the coated wells and incubated at $37^{\circ} \mathrm{C}$ for 1h. After washing, $100 \mu \mathrm{L}$ of biotinylated antibody diluted 1:1000 was added and incubated at $37^{\circ} \mathrm{C}$ for 1h. Wells were washed again and $100 \mu \mathrm{L}$ of streptavidin-horseradish peroxidase (HRP, diluted 1:1000) was added and incubated at $37^{\circ} \mathrm{C}$ for 1 h.After the final washing, color development was carried out by TMB (Sigma Biochemical Co., Ltd.), and the absorbance value was read at $450 \mathrm{~nm}$.

\section{Determination of FSH hormone levels}

The levels of FSH in serum obtained from the experimental and control rabbits was determined by radioimmunoassay. The assay kit was purchased from the Northern Institute of Biotechnology. The range of the standard curve was adjusted to be consistent with the range of normal animal hormone levels, as recommended by the manufacturer..

\section{Statistical analysis}

Results are expressed as mean \pm standard deviation. Data were analyzed by one-way analysis of variance (ANOVA) with Duncan's Multiple Range test used for pairwise comparisons. All calculations were performed with the SAS 9.2 software (SAS Inst., Cary, North Carolina, USA). Values were considered significantly different at $P<0.05$.

\section{Availability of data and materials}


Read Archive (SRA), and the accession number is KP-113678.1.

159

160

161

162

163

164

165

166

167

168

169

170

171

172

173

174

175

\section{Results}

\section{Cloning of the Ye Mule Aries sheep INHa gene coding region and construction of recombinant}

\section{plasmid}

Total RNA extracted from the ovary tissue of Ye Mule Aries sheep (absorbance of A260/A280, 1.9) was subjected to agarose gel electrophoresis. Two bands corresponding to the $18 \mathrm{~S}$ and $28 \mathrm{~S}$ rRNA were clearly visible (Figure 1A), indicating that no degradation occurred in the extraction process. Total RNA from the ovary tissue of Ye Mule Aries sheep was reverse transcribed and amplified by PCR using Oligo dT primers. The obtained product was subjected to agarose gel electrophoresis and yielded a specific band corresponding to the length of 1109 bp (Figure1B), which was preliminarily identified as the Ye Mule Aries sheep INH $\alpha$ subunit coding region. Subsequently, the product was incorporated into the PMD18-T vector and transformed into E. coli DH5a competent cells. The identity of the cloned gene (KP-113678.1) was confirmed by PCR, restriction enzyme digestion, and sequencing.

In order to express INH $\alpha$ in eukaryotic organisms, the recovered and purified INH $\alpha$ subunit gene was ligated with a linearized eukaryotic expression vector, pEGFP-N1. The ligation product was transfected into E. coli DH5a competent cells, which were cultured in the presence of kanamycin. The formed colonies were verified by PCR and restriction enzyme digestion (Figure 1C). Moreover, positive colonies were sequenced (Shanghai Shenggong Biological Engineering Technology Service co., LTD); the obtained 
176

177

178

179

180

181

182

183

184

sequence was consistent with that of the cloned gene, indicating that the pEGFP-INH $\alpha$ eukaryotic expression plasmid was successfully constructed.

\section{Molecular biology analysis of Ye Mule Aries sheep INHa}

The cloned expression vector pMD18-INH $\alpha$ was sequenced and detected by Shanghai Shenggong Bioengineering Co., Ltd. The results showed that the full length of the inhibin gene was 1109 bp, in accordance with the target band length, of which $1083 \mathrm{bp}$ constituted the open reading frame (ORF). The ORF consists of the start codon ATG, stop codon TAA, and contains the complete INH $\alpha$ subunit coding region, which codes for 360 amino acid residues. The $\mathrm{A}, \mathrm{T}, \mathrm{G}$, and $\mathrm{C}$ content in the cDNA sequence of the INH $\alpha$ gene was analyzed using DNAMAN software. The percentages of each nucleotide were $13.6 \%$, $20.3 \%, 30.0 \%$, and $36.1 \%$, respectively. The total $\mathrm{G}+\mathrm{C}$ content $(66.1 \%)$ was higher than that of $\mathrm{A}+\mathrm{T}$ $(33.9 \%)$. The calculated molecular weight of the protein was 39729 Da. Sequence comparison with the GenBank Ovis aries sequence (accession number: XM_004004955.1) revealed two point mutations (G580A, A636G), giving a nucleotide sequence homology of $96.94 \%$ and amino acid homology of $98.90 \%$. Moreover, the nucleotide sequence of the peptide moiety was the same. Additionally, SignalP4.1 software (http://www.cbs.dtu.dk/services/SignalP/) analysis predicted that there was a signal peptide cut point between the 17 th and 18 th amino acids of the $\mathrm{INH} \alpha$ protein $(\mathrm{D}=0.861$, D-cutoff $=0.450)$. Thus, the entire protein includes a 17 amino acid signal peptide and a 343 amino acid mature peptide (Figure2A). Tthe NCBI database (http:/www.ncbi.nlm.nih.gov/Structure/cdd/wrpsb.cgi) on-line tool Conserved Domain Search Service identified the presence of a transforming growth factor (TGF)-beta domain of at the site from amino acid 253 to 360 of the INH $\alpha$ protein. Moreover, the growth factor TGF-beta domain and one 
196

197 (Figure 2B).

198 (Figure 2C).

transforming growth factor TGF- $\beta$ family member active domain were identified at amino acids 256 to 360

Results obtained using DNAMAN software showed that the length of the amplified INH $\alpha$ gene was $1109 \mathrm{bp}$ and the homology to the sequence of human and gorilla genes was $84.4 \%$ and $84.3 \%$, respectively. The homology to cattle, horse, goat, sheep, pig, wild boar, dog, cat, rabbit, Mus musculus, brown rat, and rainbow trout genes was $95.2 \%, 86.1 \%, 97.9 \%, 99.8 \%, 88.1 \%, 88.4 \%, 83.6 \%, 85.5 \%, 83.4 \%, 80.4 \%$, $79.0 \%$, and 51.5\%, respectively. The comparison of the Ye Mule Aries follicle inhibin gene with other animals revealed that Ye Mule Aries sheep gene had the highest homology with sheep, followed by goat, cattle, wild boar, pig, horse, cat, human, large orangutan, dog, rabbit, Mus musculus, brown rat and rainbow trout genes. This data shows that the INH $\alpha$ gene has relatively high homology between different animals, which may indicate that the ability of INH $\alpha$ immunization to increase fecundity is preserved across species

The phylogenetic tree analysis of the Ye Mule Aries INH $\alpha$ gene by Mega5.0 software indicated that this gene follows the expected evolutionary genetics, from aquatic to terrestrial animals, and from low to high organisms. Based on the alignment of the homologues of the INH $\alpha$ subunit gene between the Ye Mule Aries sheep and other animals, the phylogenetic tree clearly reflects the evolutionary genetic characteristics of the organism (Figure 2D).

\section{Identification of recombinant plasmids in BHK cells by RT-PCR and Western blot}

The transfection efficiency of the recombinant plasmid (pEGFP-INH $\alpha$ ) in BHK cells was analyzed $48 \mathrm{~h}$ after transfection on the basis of green fluorescence (Figure 3A.B.C). Moreover, a specific band of 1109 
216 bp was detected in BHK cells by RT-PCR, which was absent in non-transfected BHK cells (Figure 1D).

217 The expression of the recombinant plasmid pEGFP-INH $\alpha$ was also confirmed by detection of a specific

218 40kDa band in Western blot assay. Thus, the pEGFP-INH $\alpha$ plasmid was successfully constructed and

219 expressed in eukaryotic cells (Figure 3D).

\section{Antibody titer in blood}

The level of anti-inhibin antibody in the blood of the immunized rabbits, measured by optical density

222 (OD), gradually increased from day 10 after the first immunization. The initial immunization was followed

by the booster immunization after 10 days. All OD measurements were significantly higher in the injected

animals than in the control group. These results indicate that antibody production was rapidly stimulated in

the rabbits by the primary immunization, and the antibody level in the blood continued to rise after the second immunization, while anti-inhibin antibody was not produced in the control group (Table 1).

\section{Plasma FSH level}

After the initial immunization, the levels of FSH in the serum of the immunized group were slightly higher than in the control group. Ten days after the first immunization and 10 days after the second booster immunization, the serum FSH concentration in the immunized rabbits was significantly higher than in the controls. This result indicates that the first immunization with INH $\alpha$ caused a slight increase in serum levels of FSH, which were further significantly increased following the booster immunization (Table 2).

\section{Discussion}

Previously, the mechanisms regulating reproductive traits in animals have been examined in the sheep ${ }^{[29]}$, 
235 cattle $^{[30]}, \operatorname{pigs}^{[31]}$, humans ${ }^{[32]}$, and mice ${ }^{[33]}$. The present study represents the first effort to clone the INH $\alpha$

236 subunit gene of the Ye Mule Aries sheep. The gene has a coding region of $1109 \mathrm{bp}$, and the complete open

237 reading frame of this sequence contains 1083 nucleotides encoding 360 amino acids. The first 17 amino

238 acids are predicted to function as a signal peptide and amino acids 18 to 360 form the remainder of the

239 mature INH $\alpha$ protein. The domain analysis of INH $\alpha$ protein showed that this protein contains one TGF

240 family domain and one TGF precursor superfamily domain, and has the activity of autocrine and paracrine

241 growth factors. It binds to the TGF family receptors and TGF superfamily receptors and participates in the

242 growth and development of the pituitary, gonads, placenta and other organs. ${ }^{[34-36]}$. By conducting a

243 comparison analysis, we showed that the homology of the nucleotide and amino acid sequences of the Ye

244 Mule Aries, common sheep, goat, and domestic cattle were over 95\%; this finding was supported by the

245 functional bioinformatics analysis of the INH $\alpha$ protein of the Ye Mule Aries.

246 In this study, we have successfully constructed the eukaryotic expression plasmid pEGFP-INH $\alpha$ and

247 expressed it in BHK cells, along with the eukaryotic expression vector pEGFP-N1 coding for the enhanced

248 green fluorescent protein (EGFP), which was used to detect the expression of exogenous genes in vitro.

249 The expression vector is more convenient for detecting the expression of the fusion gene ${ }^{[37]}$. The eukaryotic

250 expression system developed here overcomes certain deficiencies present in prokaryotic expression systems

251 because the expression product retains the natural activity of the original protein. Moreover, the expression

252 product is non-toxic and easy to purify, making this system increasingly attractive ${ }^{[38]}$.

253 Previous work has shown that fertility-regulating inhibitors can bind to activin, thus effectively

preventing morphological changes in granulosa cells induced by activin, resulting in specific inhibition of 
255 FSH release and the maintenance of normal ovarian function. Proper control of FSH is vital due to its effects

256 on follicular growth, development, luteinization, and regulation. Thus, the function of granulosa cells

257 ultimately determines the luteinization and atresia of follicles ${ }^{[39]}$. Gene immunization is based on the same

258 basic principles as standard immunologic procedures, and inhibin gene immunization is based on

259 conventional gene immunization and INH ${ }^{[40]}$. Therefore, the inhibin antigen-encoding gene can be inserted

260 into a eukaryotic vector and transformed into the animal, leading to the synthesis of the inhibin antigen

261 protein by the transcriptional system of host cells and its secretion. These processes trigger the generation

262 of the specific immune response of the host and production of an anti-inhibin antibody to neutralize the

263 follicle inhibin. The resulting interaction between the proteins reduces the levels of inhibin, thereby

264 increasing the ovulation rate and sperm production in animals ${ }^{[41]}$. Given the regulatory mechanism of the

265 inhibin gene and the negative feedback regulation of FSH, as well as current genetic vaccine methods, such

266 as the imatin DNA vaccine pINH immunization of mice ${ }^{[42]}$, eukaryotic expression plasmid pcINH active

267 immunization of rats ${ }^{[43]}$, pCIS recombinant plasmid active immunization of rats [44], and other

268 immunization methods, the results obtained here indicate that inhibin gene immunity can promote follicular

269 development and increase plasma FSH levels.

270 In this study, a pEGFP-INH $\alpha$ plasmid was constructed and adopted a scientific immunization method to

271 actively immunize rabbits using the corresponding adjuvant. Anti-inhibin antibodies could be detected in

272 the blood after the first immunization. However the titer of antibodies remained low until the second

273 immunization, which increased antibodies production and resulted in higher titer of the egg yolk antibody

$274^{[45]}$. Our finding provides a basis for further investigation of genetically engineered inhibin vaccines, 
275

276

277

278

279

280

especially using genetic recombination technology which has greatly simplified this process. Nevertheless, for practical applications, some macromolecular proteins will require specific structure analysis and selection of suitable vectors and strains to ensure correct expression and preserve the structural and physical properties of the Inhibin A subunits ${ }^{[46]}$. This strategy opens a novel avenue for the establishment of more specific monoclonal antibodies and has great potential as a new tool for improving the overall fecundity of animals.

Importantly, increasing the fecundity of sheep through immunization has unique advantages, such as high efficiency, stability, simplicity of operation, and broad applications, and thus deserves widespread research attention. A large number of experiments on merino sheep and the merlin merino hybrid ewes in the border area have confirmed that active inhibin immunization can increase the average ovulation of each ewe from 1.2 to $4.0^{[47]}$. In addition, several experimental approaches proved that inhibin immunization not only increases the rate of ovulation but also increases the number of lambs ${ }^{[48-49]}$, as well as ewes ${ }^{[50]}$, mice ${ }^{[51]}$ and rats ${ }^{[52]}$. Inhibin gene immunization can theoretically reduce the level of inhibin in vivo for an extended time, and its immune effect should be equivalent to or better than conventional immunity ${ }^{[47,49,50]}$.

Inhibin gene immunization can lower the levels of inhibin over a long time. The immune effect should be comparable to, or even better than, the effect of routine immunization. As a result, the technology offers the advantages of high stability, simple operation, and easy production. It can be used in correcting past genetic selection, embryo transfer, superovulation, and hormone-induced twins technology. Thus, inhibin gene immunization became in recent years the focus of intense research aiming at increasing the lambing rate of sheep. Further research on the mechanism of action and physiological response pathways of the 
295 inhibin gene will, most likely, benefit the rapid, healthy, and sustainable development of the sheep industry,

296 and solve the "lambing rate" problem of Xinjiang sheep in the future.

\section{Conclusion}

The present study showed that the Ye Mule Aries sheep follicle inhibin gene was successfully integrated into a highly efficient and stable INH $\alpha$ eukaryotic expression system yielding a biologically active protein.

to improve the fertility and production performance of animals via immunization-based reduction of the negative feedback of inhibin on the follicle stimulating hormone, estrogen.

\section{Author address}

Animal Genetics, Breeding and Reproduction of Ningxia University Agricultural College, P.O.Box 750, China.

\section{Acknowledgements}

The authors thank all animal keepers and farmers who have provided research material for the experiments. concern, help, and support. 


\section{References}

325 [1].Wang Jianchen, Zhang Xiaorong. Regulation of animal reproduction[M]. Hefei: Anhui Science and 326 Technology Press, 1998:1.

327 [2].Medan MS, Arai K Y,Watanabe G,Kazuyoshi TAYA.2007 Inhibin;Regulation of reproductive function and 328 practical use in females[J].Animal Science Journal,2007,78(1);16-27.

329 [3].Meldi K M,Gaconnet G A,Mayo K E;DNA Methylation and histone modifications are associated with 330 repression of the inhibin a promoterin the rat corpus luteum[J]. Endocrinology, 2013, 153(10): 4905.

331 [4].H, Kaneko, Y, Nakanishi,S, Akagi,K, Arai ; K, Taya,G, Watanabe,S, Sasamoto ,Y, 332 Hasegawa.Immunoneutralization of inhibin and estradiol during the follicular phase of the estrous cycle in cows [J]. Biol Reprod, 1995, 53(4): 931-939. 
334

335

336

337

338

339

340

341

342

343

344

345

346

347

348

349

350

351

352

353

354

355

356

357

358

359

360

361

362

363

364

365

366

367

368

[5].ROSER JF, MCCUE PM, HOYE E. Inhibin activity in the mare and stallion [J]. Domest Anim Endocrinol, 1994, 11(1): 87-100.

[6].FINDLAY JK, CLARKE IJ, ROBERTSON DM. Inhibin concentrations in ovarian and jugular venous plasma and the relationship of ihnibin with follicle-stimulating hormone and luteinizing hormone during the ovine estrous cyle [J]. Endocrinology, 1990, 126(1): 528-535.

[7].Y, Nambo; H, Kaneko ; S, Nagata ; M, Oikawa ; T, Yoshihara ; N, Nagamine ; G, Watanabe ; K, Taya. Eeffct of passive immunization against ihnibin on FSH secretion follicular genesis and ovulation rate during the follicular phase of the estrous cycle in mares [J]. Therio genology, 1998, 50(4): 545-557.

[8].FANGXIONG SHI ; KEIJI MOCHIDA ; OSAMU SUZUKI. Development of embryos in super ovulated guinea pigs following active immunization against the ihnibin alpha-subunit [J]. Endocr J, 2000, 47(4): 451459.

[9].HiroshiKogoaKotaro,Takasaki,SatoshiTakeo,GenWatanabe,KazuyoshiTaya,ShujiSasamoto.A role of prostaglandin in the secretion of ihnibin and oestradiol-17beta in equine chorionic gonado trophin-primed rats [J].Eur J Pharmacol,1993,231(3): 481-484.

[10].KNIGHT P G, GLISTER C. Potential local regulatory functions of inhibins, activins and folliculostatin in theovary[J]. Reproduction, 2001, $121: 503-512$.

[11].C, Li,Y L, Zhu ,J H, Xue,S L, Zhang, Z, Ma ,Z D, Shi.Immunization against inhibin enhances both embryo quantity and quality in Holstein heifers after super ovulation and insemination with sex sorted semen[J]. Therio genology, 2009, 71(6) : 1011-1017.

[12].Vale W, Rivier C, Hsueh A, Campen C, Meunier H, Bicsak T, Vaughan J, Corrigan A, Bardin $\mathrm{W}$, Sawchenko P.Chemical and biological characterization of the inhibin family of protein hormones[J].Recent Prog HormRes, 1988,4:I-34.

[13].Medan MS1, Akagi S, Kaneko H, Watanabe G, Tsonis CG, Taya K.Effects of reimmu nization of heifers against inhibin on hormonal profiles and ovulation rate [J].Reproduction,2004,128;475-482.

[14].Harumichi, Ishigame,Mohamed S, Medan,Gen, Watanabe, Zhanguan, Shi ,Hisahi, Kishi, Koji Y, Arai, Kazuyoshi, Taya.A NewAlternative Method for Superovulation Using Passive Immunization Against Inhibin in Adult Rats[J].Biol Reprod,2004,71;236-243.

[15.]N T, Kusina,R L, Meyer, K M, Carlson, J E, Wheaton.Passive immunization of ewes against an inhibin like peptide increases follicle stimulating hormone concen trations, ovulation rate, and proliflcacy in spring-mated ewes[J].Anim Sci, 1995, 73(5) : 1433-1439.

[16].FRAY M D, WRATHALL J H, KNIGHT PG. Active immunization against inhibin promotes a recurrent increase in litter sizein sheep[J].Vet Rec, 1994, 134(1) : 19-20.

[17].K M, Henderson, P, Franchimont ,M J, Lecomte-Yerna, N, Hudson, K, Ball.Increase in ovulation rate afer active immunization of sheep with inhibin partially purified from bovine follicular fluid[J].Endocrinol,1984,102(3) : 305-309. 
369 [18].J E, Wheaton, R L, Meyer,R H, Jones, A J, Kramer.Effectsofpas.sive immunization using antibody against 370 an alpha-inhibin peptide on follicle-stimulating hormone concentrations and litter size in sows 371 [J].Theriogenology,1998,49(4) : 813-822.

372 [19].D G, Morris, M G, McDermott,M G, Diskin, C A, Morrison, P J, Swift,J M, Sreenan.Effect of immunization 373 against synthetic peptide sequences of bovine inhibin alpha - subunit on ovulation rate and twin-calving rate in 374 heifers[J].Reprod Fertil,1993,97(1):255-261.

375 [20].Wang Shuilian, Xue Liqun, XING Chaofang,CHENG Xiaojun,CUI Xianli,YANG Liguo. Effects of 376 follistatin and GFP fusion gene vaccine on ovarian and reproductive hormones in rats[J] Chinese Journal of 377 Veterinary Medicine 2012, Vol.32 No.2: 309-313

378 [21].MAO dachan, Yang liguo, ye rong, JIANG Xunping.Effects of inhibin (1 32) gene immunity on follicular 379 development and reproductive hormones in rats [J]. Chinese agricultural science, 2003,36 (12) : 1554-1559.

380 [22].Wang shuilian, feng jian zhong, li wenping. Effects of non-resistance screening inhibin gene vaccine 381 immunization on postpartum uterine involution in cows $[\mathrm{J}]$ journal of hunan agricultural university (natural 382 science edition) 2014, 40(4): 395-398

383 [23].C, Li ,Y L, Zhu,J H, Xue ,S L, Zhang,Z, Ma ,Z D, Shi.Immunization against inhibin enhances both embryo 384 quantity and quality in Holstein heifers after super ovulation and insemination with sex-sorted 385 semen[J]. Theriogenology,2009,71(6):1011-1017.

386 [24].LI Chao,MEI Cheng,ZHU Yulin,XUE Jianhua,ZHONG Shoukun,MA Zhu,ZHANG Shengli,SHI Zhendan.. 387 Enhancing embryo yield in superovulated Holstein heifers by immunization against inhibin[J] .Reprod Domest 388 Anim ,2009,44(5):735-739.

389 [25].Liu guiqiong, jiang yiping, ding jiatong, Yang liguo. Effects of active immunization with pig follicle 390 inhibitor on goat reproduction [J]. Journal of animal husbandry and veterinary medicine, 2003,34(1),37-39.

391 [26].Tianyunbo,HUANG yunmao. Effects of active immunosuppressant on reproductive performance

392 of goats $[\mathrm{J}]$ guangdong agricultural science, $2010,122-123$.

393 [27].Jergen anivash, qurmunis khan jahan, imin sulaiman, hamiti hakaimov, ishengchun, yiran. Determination 394 of slaughter of yomuler white sheep (provisional name) in emin county, xinjiang. Xinjiang agricultural 395 science,2006,43(5):443-445.

396 [28].Karumnihan jahan, jahan arnivash. Comparative study on the slaughter performance of

397 eimullah white sheep [J]. animal husbandry and veterinary, heilongjiang province, 2010,8 (top) : 65-66

398 [29].FORAGERG, RINGJM, BROWNRW. Cloning and sequence analysis of cDNA species coding for the two 399 subunits of inhibin from bovine follicular fluid[J]. Proc Natl Acad Sci USA, 1986, 83(10): 3091-3095.

400 [30].RODGERS RJ. Cloning of the inhibin/activin beta B subunit gene from the Booroola merino sheep[J]. J 401 Mol Endocrinol, 1991, 6(1): 87-93. 
402 [31].MASONAJ, HAYFLICKJS, LINGN. Complementary DNA sequence of ovarian follicular fluid inhibin 403 show precursor structure and homology with transforming growth factor-beta[J]. Natrue, 1985, 318(6047): 659404663.

405 [32].MASON AJ, NIAFL HD, SEEBURG PH. Structure of two human ovarian inhibins[J]. Biochem Biophys 406 Res Commun, 1986, 135: 957-964.

407 [33].WOODRUFF TK, MEUNIER H, JONES PB. Rat inhibin: molecular cloning of alpha-and beta-subunit 408 complementary deoxyribonucleic acids and expression in the ovary[J]. Mol Endocrinol, 1987, 1(8): 561-568.

409 [34].Ying SY.Inhibins activins and follistatins:gonadal proteinmodu Latingthe secretion of FSH[J].Endocrine 410 Reviews,1988,9:267-293.

411 [35].ValeW, RivierJ.Purification and characterization of an FSH releasing protein from

412 Porcineovarian follicuLar fluid[J].Nature.1986,321:776-779.

413 [36].FindlayJK.Anupdateonthe roles of inhibin,activins and follistratin as locaIregu Lar of 414 foIlicuLogenesis[J].BioReprod.1993,48:15-23.

415 [37].Chen Y,MuLler J D, Ruan Q,etal.MolecuLar brightness charac-terization of EGFP in vivo by fluorescence 416 fluctuation spectrosco-py.Biophys[J],2002,82(Pt1):133-134

417 [38].Deng jixian, Yang xiurong, wei yingming, jiang hesheng.Eukaryotic expression of follicle inhibiting gene 418 in marsh buffalo [J]. Chinese animal husbandry and veterinary, 2011, vol. 38, no. 9, 57-60.

419 [39].Findlay J K.An update on the roles of inhibin,activin,and follistatin as local regulators of 420 folliculogenesis.Biol Reprod,1993,48(1):15 23. $\square$

421 [40].Xun-ping jiang.Principles and methods of genetic immunity [M]. Beijing: science press, 2004

422 [41].Ning zhang yong, yu shu min, liu wenju.Advances in gene immunology [J].Experimental animal science 423 and management, 2003,20(3):28-36

424 [42].JIANG Xunping,YANG Liguo,LIU Guiqiong,Mao DG,Ye R. Effects of immunosuppressant gene on the 425 reproduction of mice, Chinese journal of veterinary medicine, 2002,22:368-370

426 [43].Mao DG, Yang LG, Ye R, Jiang XP. Effect of Inhibin a(1-32 ) Gene immunization on the Follicular 427 Development and Reproductive Hormones in Rats. Agricultural Sciences in China,2003, 2: 337-343

428 [44].MAO dachan, Yang liguo, ye rong, JIANG Xunping. The effect of inhibin on follicular development and 429 reproductive hormones in rats was only (1-32) [J].Chinese agricultural science, 2003,36 (12) : 1554.1559

430 [45].Zhang honglin, zhou hongxia, zhou yifei, etal. Preparation of DNA yolk antibody inhibiting quality granule 431 (pCISI) [J]. Journal of agriculture, jiangsu, 2010, 26(4): 891-893.

432 [46].Yunnan documentary;Chen fengyi;Tian Ping;LiuWanLin;XiaoZhenBai.Significance of calcitonin in early 433 diagnosis of neonatal sepsis [J].Chinese journal of applied pediatrics, December 18, 2003, issue 12:763-764. 
434 [47].R G, Forage ; R W, Brown ; K J, Oliver ; B T, Atrache ; P L, Devine ; G C, Hudson ; N H, Goss ; K C, 435 Bertram ; P, Tolstoshev; D M, Robertson.Immunization against an inhibin subunit produced by recombinant 436 DNA techniques results in increased ovulation rate in sheep[J].J.Endocrin01, 1987,114(2):R1-R4

437 [48]. Wheaton J.E,Carlson K.M, Kusina N. T. Active and passive immunoneutralization of inhibin increases 438 follicle-stimulating hormone levels and ovulaton rate in ewes[J]. Biology of Reproduction, 1992, 47(3) : $439 \quad 361-367$

440 [49].R G, Glencross ; E C, Bleach; S C, Wood; P G, Knight.Active immunization of heifers against 441 inhibin:effects on plasma concentrations of gonadotrophins, steroids and ovarian follicular dynamics during 442 prostaglandin-synchronized cycles[J].Journal of Reproduction and Fertility, 1994,100:599-605

443 [50].J H, Wrathall ; B J, McLeod ; R G, Glencross ; A J, Beard ; P G, Knight.Inhibin immunoneutralization by 444 antibodies raised against synthetic peptide sequences of inhibin alpha subunit:effects on gonadotrophin 445 concentrations and ovulation rate in sheep[J].Journal of Endocrinology, 1990,124(1):167-176

446 [51].C R, Sewani ; M M, Bagdasarian ; J J, Ireland ; M, Bagdasarian.Display of an inhibin epitope in a surface447 exposed loop of the E. coli heat-labile enterotoxin B subunit[J].Vaccine,1998,16(17):161 1·1619

448 [52]. Xia Yin, zhao xuting, zhang xiaodonEffects of inhibin passive immunity on ovulation rate and plasma 449 estradiol and progesterone in rats [J].Journal of animal husbandry and veterinary medicine, 1999,30 (1) : 7-11 


\section{Figure 1}

Cloning and Verification of objective Gene INH

A:Agarose electrophoresis of total RNA;1.2.3. The total RNA were Ye Mule Aries ovarian tissue. Two ribosomal RNA bands of $18 \mathrm{~S}$ and $28 \mathrm{~S}$ were clearly visible indicating that the RNA of Ye Mule Aries ovarian tissue no degradation occurred in the extraction process.B:PCR product of INHa subunit gene in Ye Mule cries;M, DL5000 DNA Marker; 1and 2 The amplification product of INHa gene.C:Enzyme digestion identification of recombinant plasmid PEGFP-INH $\alpha ; M, D L 5000$ DNA Marker; 1and 2 pEGFP-INHa double enzyme digestion products. The eukaryotic expression vector pEGFP-INHa was verified by PCR and enzyme digestion.D:RT-PCR identification of recombinant plasmid expression in cells;M: DL5000 DNA Marker;1.pEGFP-N1 in BHK cells expressed;2. pEGFP-INH $\alpha$ in BHK cells;3.No BHK cell transfection expressed. RT-PCR proved that the constructed vector was successfully transfected into BHK cells. 

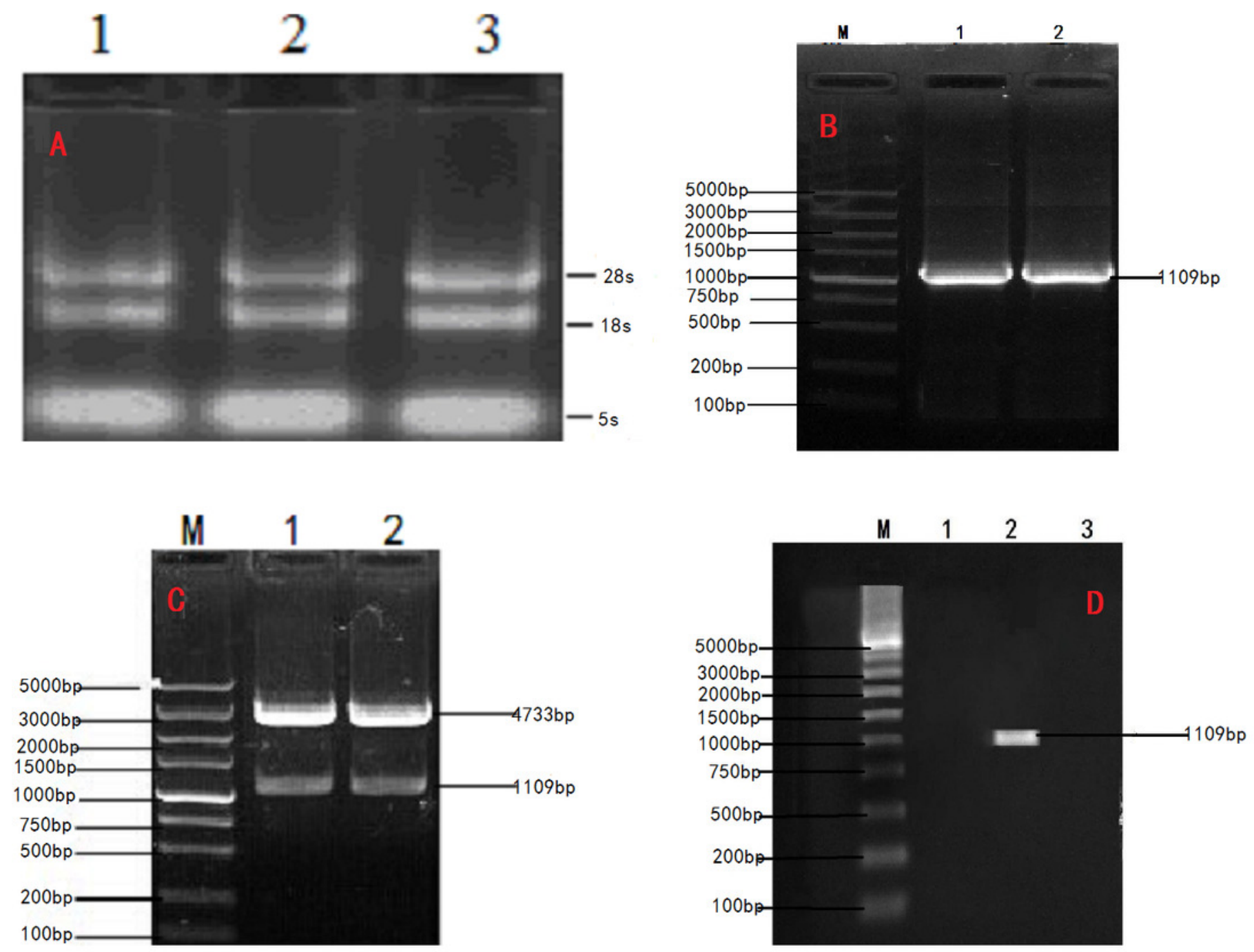


\section{Figure 2}

Molecular biology analysis of Ye Mule Aries sheep INH $\alpha$

A.By signalP4.1 software was used to predict signal peptides of Ye MuLe Aries INH

gene.B.Structural domain of INH $\alpha$ protein analyse ,identified Ye Mule Aries sheep growth factor TGF-beta domain and one transforming growth factor TGF-ß family member active domain are present.C.Ye Mule Aries INH $\alpha$ Sequence alignment analyse with other species, these data represents that the follistatin gene is highly conservative.D.Ye mule Aries INH $\alpha$ gene DNA sequences of genetic evolution analyse, by evolutionary tree, we can find that the variation of follistatin gene of Ye Mule Aries is also in accordance with the natural law of animal evolution.

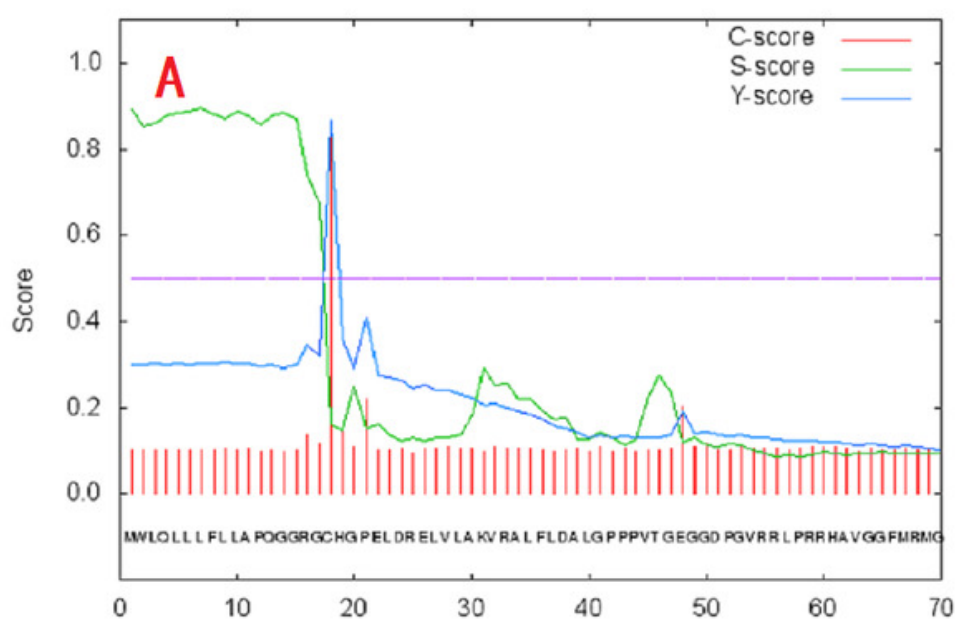

Percentldentity

\begin{tabular}{|l|l|l|l|l|l|l|l|l|l|l|l|l|l|l|l|}
\hline & 1 & 2 & 3 & 4 & 5 & 6 & 7 & 1 & 9 & 10 & 11 & 12 & 15 & 14 & 15 \\
\hline
\end{tabular}

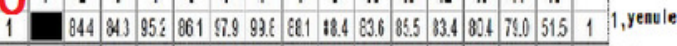

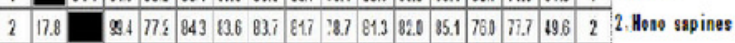

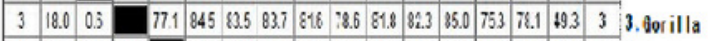

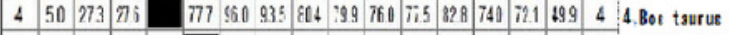

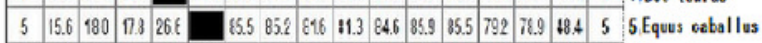

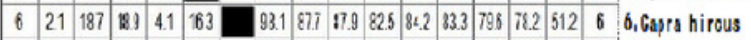

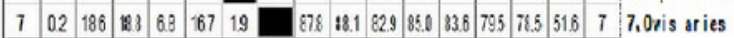

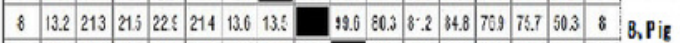

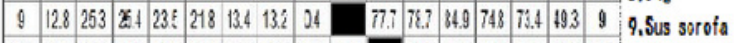

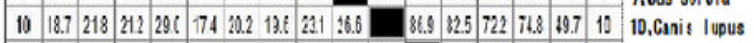

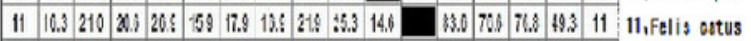

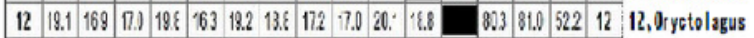

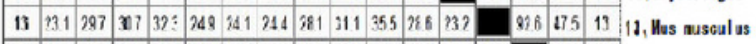

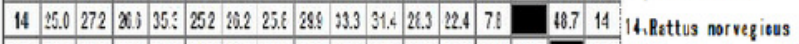

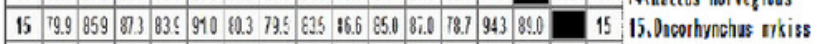
\begin{tabular}{|l|l|l|l|l|l|l|l|l|l|l|l|l|l|l|l|}
1 & 2 & 3 & 4 & 5 & 6 & 7 & 8 & 9 & 10 & 11 & 12 & 13 & 14 & 15 \\
\hline
\end{tabular}
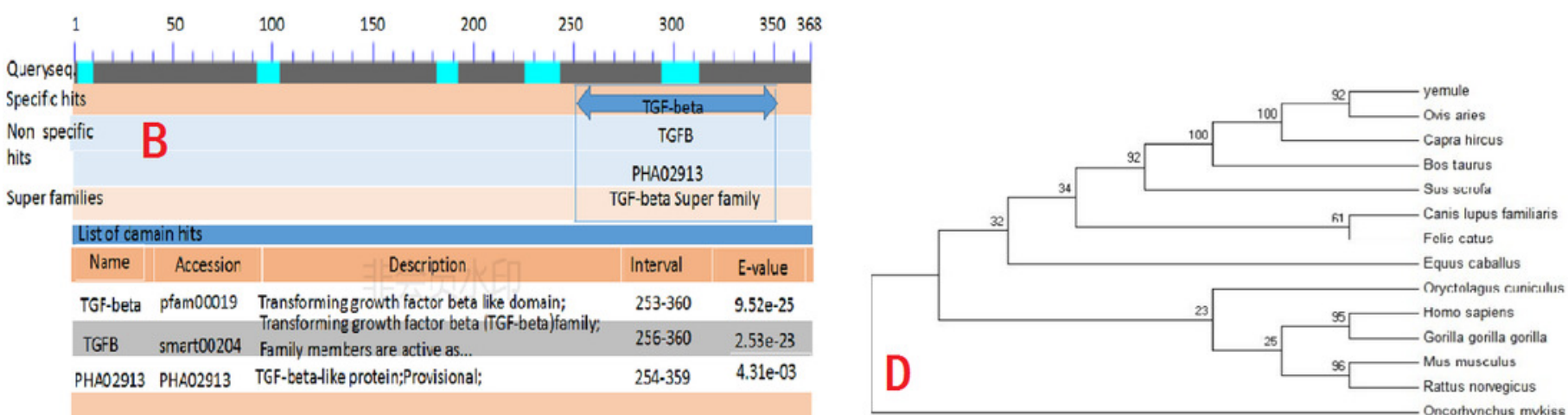


\section{Figure 3}

Cell infection Experimental Analysis and Verification of the Target Gene INH

A. pEGFP-N1 in BHK cells expressed; B. pEGFP-INH $\alpha$ in BHK cells expressed; C.No BHK cell transfection.D.Western blotting to identify protein expression in recombinant plasmidsM. proteinMaker;1.pEGFP-N1 in BHK cells expressed;2. pEGFP-INH $\alpha$ in BHK cells; 3.No BHK cell transfection expressed
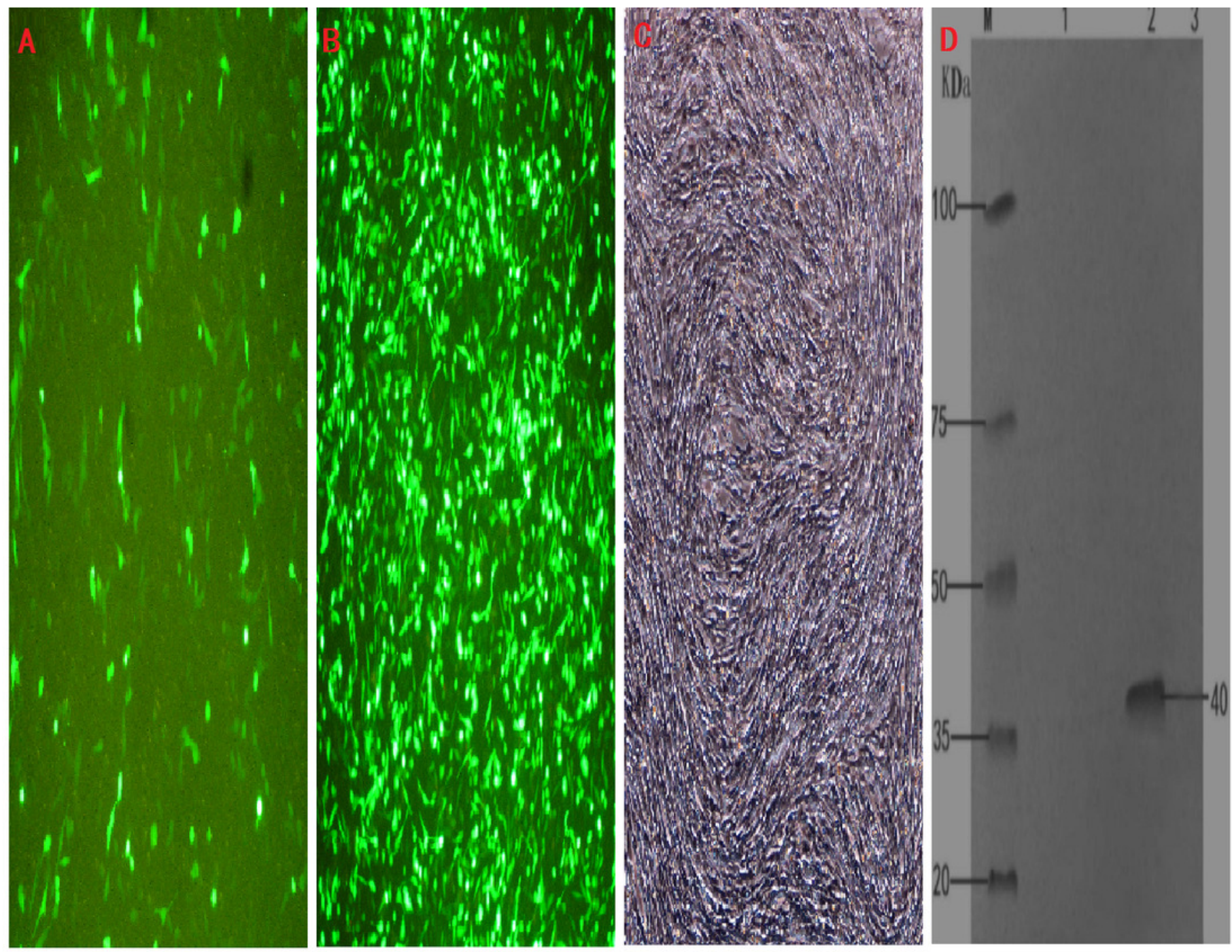


\section{Table $\mathbf{1}$ (on next page)}

Changes in inhibin antibody titer in experimental rabbit blood

Note: for data in the same column, different lowercase letters indicate significant differences $(P<0.05)$, while different uppercase letters indicate extremely significant differences $(P<0.01)$. 
1

2

Table 1 Changes in inhibin antibody titer in rabbit blood

\begin{tabular}{cccc}
\hline \multirow{2}{*}{ Processing group } & \multicolumn{3}{c}{ Antibody titer } \\
\cline { 2 - 4 } & $0 \mathrm{~d}$ & $10 \mathrm{~d}$ & $20 \mathrm{~d}$ \\
\hline $\begin{array}{c}\text { Immunization } \\
\text { group }\end{array}$ & $0.09 \pm 0.002$ & $0.75 \pm 0.147^{\mathrm{A}}$ & $1.24 \pm 0.123^{\mathrm{A}}$ \\
Control group & $0.09 \pm 0.001$ & $0.09 \pm 0.169^{\mathrm{B}}$ & $0.11 \pm 0.030^{\mathrm{B}}$ \\
\hline
\end{tabular}

3 Note: for data in the same column, different lowercase letters indicate significant differences $4 \quad(P<0.05)$, while different uppercase letters indicate extremely significant differences $(P<0.01)$. 


\section{Table 2 (on next page)}

Effect of immunosuppressive factor on serum $\mathrm{FSH}$

Note: The lowercase English letters in the same column of the table indicate that the difference is significant $(p<0.05)$. The uppercase English letters indicate that the difference is extremely significant $(p<0.01)$, and the addition and subtraction after the average is expressed as SE 
1

2

Table 2 Effect of immunosuppressive factor on serum FSH $\quad \mathrm{mIU} / \mathrm{mL}$

\begin{tabular}{cccc}
\hline \multirow{2}{*}{ Processing group } & 0d & $10 \mathrm{~d}$ & $20 \mathrm{~d}$ \\
\cline { 2 - 4 } & $1.32 \pm 0.45$ & $1.68 \pm 0.38$ & $2.68 \pm 0.34^{\mathrm{A}}$ \\
\hline $\begin{array}{c}\text { Immunization } \\
\text { group }\end{array}$ & & & \\
Control group & $1.40 \pm 0.40$ & $1.39 \pm 0.22$ & $1.35 \pm 0.16^{\mathrm{B}}$ \\
\hline
\end{tabular}

3 Note: The lowercase English letters in the same column of the table indicate that the difference is 4 significant $(p<0.05)$. The uppercase English letters indicate that the difference is extremely 5 significant $(p<0.01)$, and the addition and subtraction after the average is expressed as SE.

6 